\title{
RHINOLOGY
}

\section{Endoscopic surgical treatment of epistaxis in hereditary haemorrhagic telangiectasia: our experience}

\author{
II trattamento endoscopico dell'epistassi nella teleangectasia emorragica ereditaria: \\ la nostra esperienza \\ Fabio Pagella ${ }^{1,2}$, Alessandro Pusateri ${ }^{1}$, Eugenia Maiorano ${ }^{1,2}$, Giuseppe Spinozzi ${ }^{1}$, Sara Ugolini1 ${ }^{1,2}$, Roberta Lizzio ${ }^{1}$, \\ Rosolino Mirabella ${ }^{1,2}$, Carmine Tinelli ${ }^{3}$, Carla Olivieri ${ }^{2,4}$, Elina Matti ${ }^{1}$ \\ ${ }^{1}$ Department of Otorhinolaryngology, Fondazione IRCCS Policlinico San Matteo, Pavia, Italy; ${ }^{2}$ University of Pavia, Italy; ${ }^{3}$ Clinical \\ Epidemiology and Biometric Unit, Fondazione I.R.C.C.S. Policlinico San Matteo, Pavia, Italy; ${ }^{4}$ General Biology and Medical Genetics, \\ Department of Molecular Medicine, Pavia, Italy
}

\begin{abstract}
SUMMARY
Objectives. Hereditary haemorrhagic telangiectasia (HHT) is a rare autosomal dominant disease characterised by epistaxis. Surgical procedures for epistaxis vary from diathermocoagulation to nasal closure. The aim of this paper is to report our experience in endoscopic surgical management of epistaxis in HHT patients.

Methods. This is a descriptive, longitudinal study carried out at the Otorhinolaryngology Department of IRCCS Policlinico San Matteo in Pavia, a reference centre for the treatment and diagnosis of HHT. We retrospectively evaluated HHT patients who underwent surgery for epistaxis from 1996 to 2015, including only those treated with endoscopic surgery. Results. Among the 591 patients hospitalised and screened for HHT, 323 (54.7\%) underwent endoscopic surgery for epistaxis, for a total of 679 procedures. General anaesthesia was used in $77.2 \%$ of procedures; argon plasma coagulation was the instrument of choice in the majority of patients, followed by lasers and quantum molecular resonance technology. Conclusions. We report one of the largest cohorts undergoing endoscopic treatment of epistaxis in HHT patients. This mini-invasive surgical treatment allowed us to control epistaxis without major complications and nasal packaging and can be repeated over time. For these reasons, we recommend it as first choice in case of epistaxis in HHT patients.
\end{abstract}

KEY WORDS: hereditary haemorrhagic telangiectasia, Rendu Osler Weber disease, epistaxis, nosebleeds, endoscopy, argon plasma coagulation

\section{RIASSUNTO}

Obiettivi. L'obiettivo di questo studio è riportare la nostra esperienza nel trattamento endoscopico dell'epistassi nei pazienti con Teleangectasia Emorragica Ereditaria (HHT).

Metodi. Si tratta di uno studio longitudinale retrospettivo svolto presso l'UOC di Otorinolaringoiatria della Fondazione IRCCS Policlinico San Matteo di Pavia, centro di riferimento per la diagnosi e la cura dell'HHT. Sono stati valutati i pazienti sottoposti dal 1996 al 2015 a trattamento chirurgico delle epistassi ricorrenti, includendo solo quelli trattati con tecnica endoscopica.

Risultati. Dei 591 pazienti ricoverati e sottoposti a screening per HHT, 323 (54.7\%) sono stati sottoposti a trattamento chirurgico endoscopico per epistassi, per un totale di 679 procedure. Il 77,2\% delle procedure è stato eseguito in anestesia generale; il sistema ad Argon Plasma è stato lo strumento di scelta nella maggior parte dei pazienti, seguito dai laser e dalla quantum molecular resonance.

Conclusioni. Riportiamo una delle più ampie casistiche nel trattamento endoscopico dell'epistassi nei pazienti con HHT. Tale approccio consente di gestire i pazienti senza necessità di tamponamento nasale, è scevro da complicanze maggiori, ripetibile nel tempo e riteniamo che debba essere preso in considerazione come trattamento di prima scelta in caso di epistassi in pazienti con HHT.

PAROLE CHIAVE: teleangectasia emorragica ereditaria, malattia di Rendu Osler Weber, epistassi, endoscopia, argon plasma
Received: June 10, 2020

Accepted: October 16, 2020

Correspondence

Eugenia Maiorano

Department of Otorhinolaryngology, Fondazione IRCCS Policlinico San Matteo, piazzale Golgi 19, 27100 Pavia, Italy

E-mail: eugenia_maiorano@libero.it

Funding

None.

Conflict of interest

The Authors declare no conflict of interest.

How to cite this article: Pagella F, Pusateri A, Maiorano E, et al. Endoscopic surgical treatment of epistaxis in hereditary haemorrhagic telangiectasia: our experience. Acta Otorhinolaryngol Ital 2021;41:59-68. https://doi. org/10.14639/0392-100X-N0915

() Società Italiana di Otorinolaringoiatria e Chirurgia Cervico-Facciale

\section{(c) (1) $(2)$}

This is an open access article distributed in accordance with the CC-BY-NC-ND (Creative Commons Attribution-NonCommercial-NoDerivatives 4.0 International) license. The article can be used by giving appropriate credit and mentioning the license, but only for non-commercial purposes and only in the original version. For further information: https:// creativecommons.org/licenses/by-nc-nd/4.0/deed.en 


\section{Introduction}

Hereditary haemorrhagic telangiectasia (HHT) is an autosomal dominant disorder characterised by multiorgan systemic vascular dysplasia. The prevalence of the disease is estimated to be between 1:5000 and 1:8000 in the European population ${ }^{1}$. HHT is characterised by a highly variable phenotype and complete penetrance by the age of 40 years; vascular dysplasia leads to visceral arteriovenous malformations (AVMs) and mucosal and skin telangiectasias. Recurrent epistaxis from telangiectasias of the nasal mucosa is the most frequent symptom, which is present in more than $95 \%$ of HHT patients ${ }^{1}$. AVMs are frequently found in the lungs (15-50\% of patients), liver (32-78\%) and brain (23\%) and should be recognised in these patients since they may cause severe life-threatening complications ${ }^{1}$. The clinical diagnosis of HHT is confirmed if three of the four diagnostic Curacao criteria (positive family history, recurrent epistaxis, mucocutaneous telangiectasias, visceral AVMs) are met. Two major genes are involved in HHT: $E N G$ (OMIM \#187300) and ACVRL1 (OMIM \#600376), coding for proteins involved in the TGF- $\beta$ /BMP pathway ${ }^{1,2}$.

In HHT patients, the clinical manifestations of epistaxis are variable, from rare blood spots to patients in whom nosebleed severity can require frequent blood transfusions, with a substantial worsening in quality of life. Over the years, different grading scale systems have been proposed to quantify the severity of epistaxis related to HHT. Moreover, in recent years, to enhance the visualisation of nasal vascular structures, our group developed new methods of intraoperative endoscopy based on narrow-band imaging and fluorescein-guided endoscopy ${ }^{3,4}$. However, epistaxis in HHT remains a clinically unsolved problem; current therapies do not lead to a definitive resolution but only to temporary control of the condition. Multiple therapeutic approaches have been proposed in the literature and can be schematically classified into the destruction of telangiectasia, reduction of blood flow, reduction of trauma, improvement of protection and control of fibrinolytic activity.

Regarding medical therapy, different approaches have been proposed and described with variable results ${ }^{5-8}$. From a surgical perspective, the management of epistaxis depends on clinical severity. In patients with mild nosebleeds, various forms of mini-invasive surgical techniques including bipolar cautery, argon plasma coagulation (APC), lasers and Diego-PK Shaver treatment can be indicated, while more invasive procedures, such as modified Young's procedure, are reserved for cases of severe epistaxis 9,10 .

Various therapeutic approaches for epistaxis in HHT have been described, but there still is no general agreement on the best treatment. The purpose of this study was to de- scribe our experience in the endoscopic management of epistaxis in HHT patients, focusing on mini-invasive surgical procedures.

\section{Materials and methods}

The Department of Otorhinolaryngology of I.R.C.C.S. Policlinico San Matteo in Pavia is a national reference centre for diagnosis and treatment of HHT. After Local Ethics Committee approval (Comitato Etico di Pavia, reference number 1-29/1/14), we retrospectively reviewed data of HHT patients treated from 1996 until 2015 for nosebleeds, including demographics, surgical technique, number of procedures carried out on each patient, time between each procedure, characteristics of nasal telangiectasias, presence of septal perforation and intraoperative bleeding. Patient records were stored in a Filemaker Pro Advance database (version 14.0.1, Filemaker Inc.) and extracted for this study. Molecular analyses on peripheral blood DNA were performed as described in a previous paper: $100 \mathrm{ng}$ of genomic DNA was amplified in the coding regions of both $E N G$ and $A C V R L 1^{2}$.

The endoscopic endonasal mini-invasive surgical procedure was performed in the operating theatre under local or general anaesthesia. During surgery, patients were placed in a reverse Trendelenburg position. Careful preparation of the nasal cavities was undertaken: cottons soaked with xylometazoline chlorohydrate $0.1 \%$ and oxybuprocaine chlorohydrate $0.01 \%$ were placed in the nasal fossa and left in place for 5-10 min to decongest and clean the nasal mucosa. Surgery was performed under endoscopic endonasal control with a $0^{\circ}$ rigid $4 \mathrm{~mm}$ optic (Karl Storz and Co., Germany) to selectively treat involved mucosa and telangiectasias located along the nasal fossae. After surgery, an antibiotic ointment was placed in the nasal cavities and no nasal packing was necessary. In some patients whose intraoperative bleeding was more severe than expected and not managed elsewhere, we applied selective bipolar cauterisation or an intranasal haemostatic matrix such as Floseal (Baxter, U.S.), Surgiflo (Ethicon, U.S.), Perclot (Cryolife, U.S.), or Haemocer (BioCer GmbH, Germany) as an adjunct to local coagulation control of haemostasis. In the postoperative period, patients were periodically evaluated (every 6-12 months) for epistaxis with medical evaluation and/or follow-up phone call. In cases in which good control of epistaxis was obtained, follow-up was continued as described; in cases of worsening of symptoms, a new surgical procedure was performed. Non-responders (31 patients) were given medical therapy with oral thalidomide and excluded from the present analysis ${ }^{5}$. 


\section{Statistical analysis}

Descriptive statistics were used for demographic characteristics for this sample of patients. The Shapiro-Wilk test was used to test the normal distribution of quantitative variables. When quantitative variables were normally distributed, the results were expressed as mean value and standard deviation (SD), otherwise median and interquartile range (IQR; $25^{\text {th }}-75^{\text {th }}$ percentile) were reported. Qualitative variables were summarised as counts and percentages. The comparisons between gender or patients with one procedure versus patients with more than one procedure were performed with chi-square test for categorical variables and Student's t test (or Kruskall-Wallis test if data are skewed) for continuous variables. All tests were two-sided and $p$ values $<0.05$ were considered statistically significant. The data analysis was performed with the STATA statistical package (release 14.0, 2015, Stata Corporation, College Station, Texas, USA).

\section{Results}

Five hundred and ninety-one HHT patients, diagnosed according to the Curacao criteria, were hospitalised and screened at our department. Of these, 323 patients (54.7\%) underwent endoscopic surgery for epistaxis, for a total of 679 procedures. Concerning mutational screening, analyses were completed on 207 patients: 152 patients (73.4\%) carried a mutation in ACVRL1, while 55 (26.6\%) carried a mutation in $E N G$.

The group consisted of 182 men (56.3\%) and 141 women $(43.6 \%)$, with a mean age of 56 years at first surgery (range 5-86 years); interestingly, we found a significant difference between males (mean 53 years, SD 14 years) and females (mean 57 years, SD 15 years) regarding mean age at first surgery $(\mathrm{p}=0.0158)$.

General anaesthesia was used in 524 procedures (77.2\%), while local anaesthesia was used in 155 (22.8\%). In 175 patients $(54.2 \%)$, a single surgical procedure was effective to obtain acceptable control of epistaxis (median follow-up in this group was 48 months), while 148 patients (45.8\%) required more than one procedure over time, for a total number of 679 procedures (Tab. I). During the follow-up period, 25 patients $(7.7 \%)$ were lost and 31 patients $(9.6 \%)$ died. The mean number of surgical procedures in our group was 1.9 in females (SD 1.4), 2.3 in males (SD 1.8) and 2.1 (SD 1.6) overall. No significant difference was noted between $A C V R L 1$ and $E N G$ patients regarding the number of surgical procedures (one surgery vs two or more; $p=0.1389$ ). In patients with more than one surgery, the time between procedures was analysed (Tab. II; Fig. 1). Preoperative epistaxis severity was scored according to Pagella et al. and was moderate or severe in all patients ${ }^{6}$. Characteristics of telangiec-
Table I. Number of epistaxis-related surgical procedures performed in HHT patients.

\begin{tabular}{lcc} 
Number of surgeries & No. of patients & $\%$ \\
1 procedure & 175 & $54.18 \%$ \\
2 procedures & 56 & $17.34 \%$ \\
3 procedures & 43 & $13.31 \%$ \\
4 procedures & 19 & $5.88 \%$ \\
5 procedures & 14 & $4.33 \%$ \\
6 procedures & 5 & $1.55 \%$ \\
7 procedures & 7 & $2.16 \%$ \\
8 procedures & 2 & $0.62 \%$ \\
9 procedures & 1 & $0.31 \%$ \\
10 procedures & 1 & $0.31 \%$ \\
Total & 323 & $100 \%$ \\
\hline
\end{tabular}

tasias were analysed before the first surgery and this data was available for $160 / 323$ patients (49.5\%): according to the description performed by Pagella et al. in $2009^{6}$, the most common pattern was "mixed" (90 patients, $56.3 \%$ ), followed by the "large" (56 patients, 35\%) and "punctate" pattern (14 patients, 8.7\%) (Fig. 2). The nasal septum and lateral nasal walls were involved, respectively, in $91.9 \%$ and $91.3 \%$ of patients, and the nasal floor in $43.7 \%$ and nasal valve in $31 \%$. Interestingly, a significant difference $(\mathrm{p}=0.033)$ between males and females was found in the pattern of telangiectasias: the punctate pattern was more common in females (11 vs 3 ), while mixed and large patterns were more common in males (respectively 51 vs 39 and 33 vs 23).

In our sample of HHT patients treated with endoscopic endonasal mini-invasive technique, APC (Fig. 3) was the

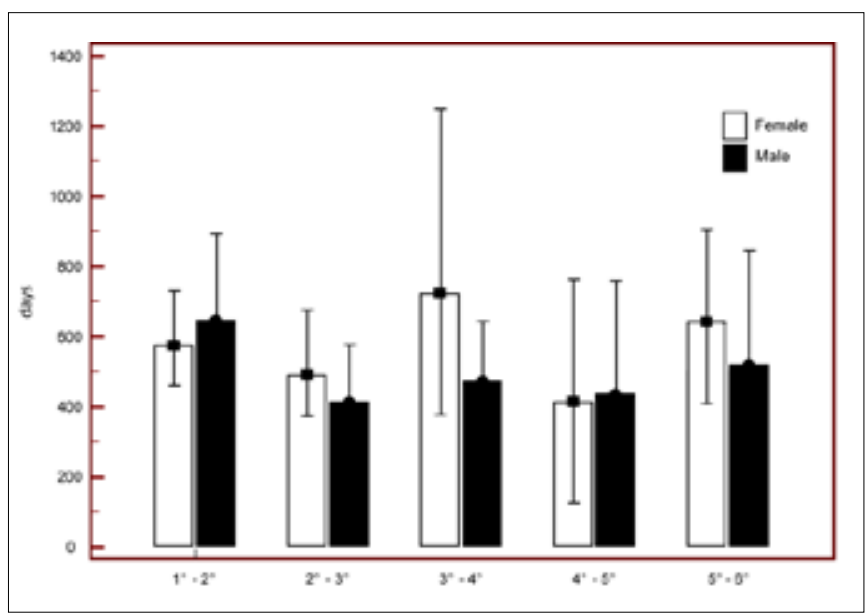

Figure 1. Plot showing the time between surgical procedures (in days) in HHT patients with more than one surgery. Columns: medians; lines: interquartile ranges. Females represented in white and males in black. 
Table II. Time between surgical procedures in patients with more than one surgery. Results are reported in days, with the median of days between surgeries in each subgroup.

\begin{tabular}{|c|c|c|c|c|c|c|}
\hline & No. of patients & Median & \multicolumn{2}{|c|}{$\operatorname{IQR}\left(25^{\text {th }}-75^{\text {th }}\right)$} & Min & Max \\
\hline First - Second & 150 & 612 & 299 & 1225 & 23 & 4979 \\
\hline Second - Third & 92 & 447 & 205 & 769 & 17 & 3810 \\
\hline Third - Fourth & 50 & 540 & 267 & 917 & 14 & 2175 \\
\hline Fourth - Fifth & 30 & 420 & 279 & 762 & 55 & 1820 \\
\hline Fifth - Sixth & 16 & 583 & 278 & 848 & 19 & 1211 \\
\hline Sixth - Seventh & 11 & 224 & 42 & 697 & 21 & 1468 \\
\hline Seventh - Eighth & 4 & 322 & 207 & 647 & 133 & 930 \\
\hline Eighth - Ninth & 2 & 345 & 311 & 379 & 311 & 379 \\
\hline Ninth - Tenth & 1 & 261 & 261 & 261 & 261 & 261 \\
\hline
\end{tabular}

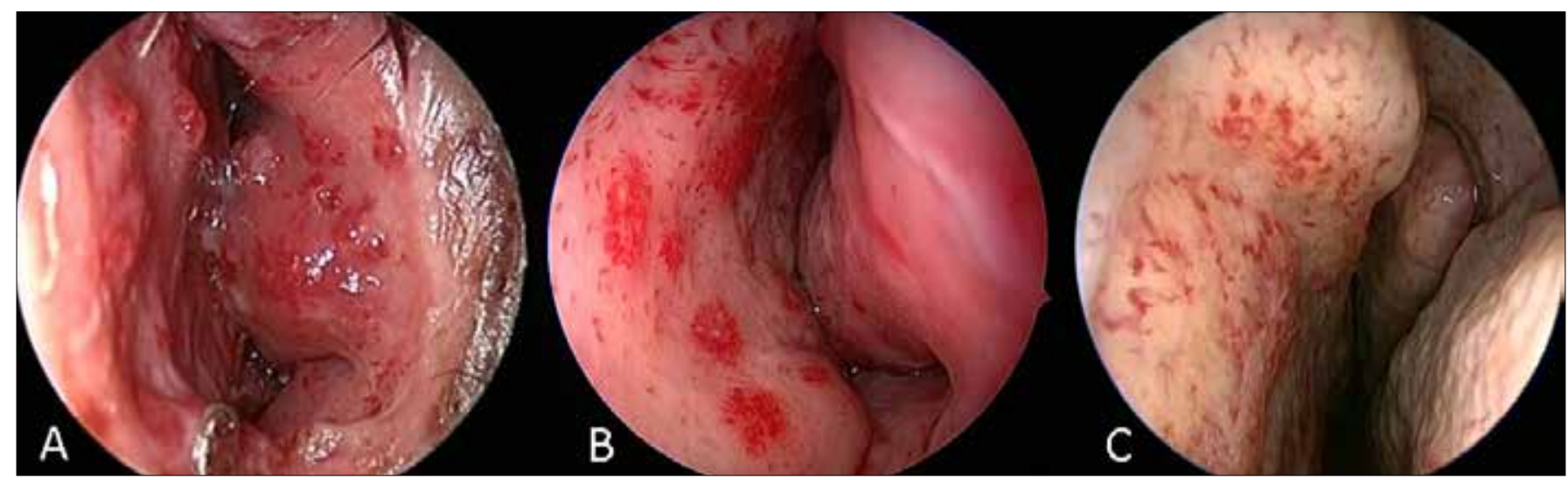

Figure 2. Nasal endoscopies in HHT patients, different patterns are shown. In (A), "large" pattern. In (B), "mixed" pattern. In (C), "punctate" pattern.

instrument of choice (661 procedures, $97.3 \%$ ), while lasers (diode, thulium) and quantum molecular resonance technology (Figs. 4,5$)$ were used in 15 procedures $(2.2 \%)$.

Since 2004, intranasal haemostatic matrices such as Floseal (Baxter, U.S.), Surgiflo (Ethicon, U.S.), Perclot (Cryolife, U.S.), or Haemocer (BioCer GmbH, Germany) were introduced in our clinical practice in order to permit adequate management of severe intraoperative bleeding and better visualisation of the intraoperative field. In our experience, we successfully used these devices during surgery in 83 procedures $(12.2 \%)$.

Septal perforation was observed in 75 patients $(23.2 \%)$. Among these, 31 patients $(41.3 \%)$ had a septal perforation before our first surgery, so in these patients the complication was not related to our treatment. On the other hand, 44 patients $(58.7 \%)$ developed a septal perforation during

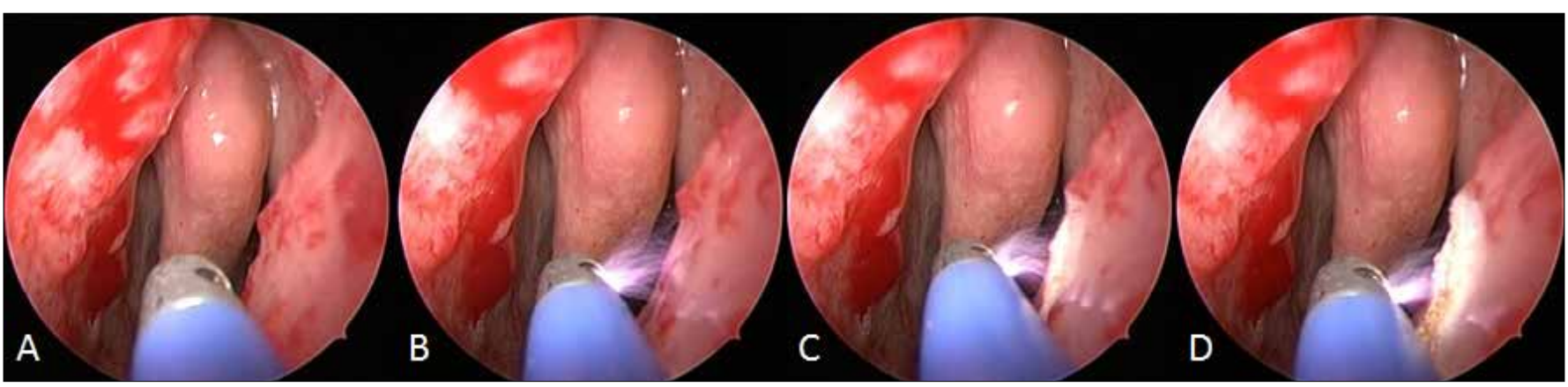

Figure 3. Intraoperative endoscopic sequence showing an APC procedure on left-side telangiectasias located on the lateral nasal wall. 


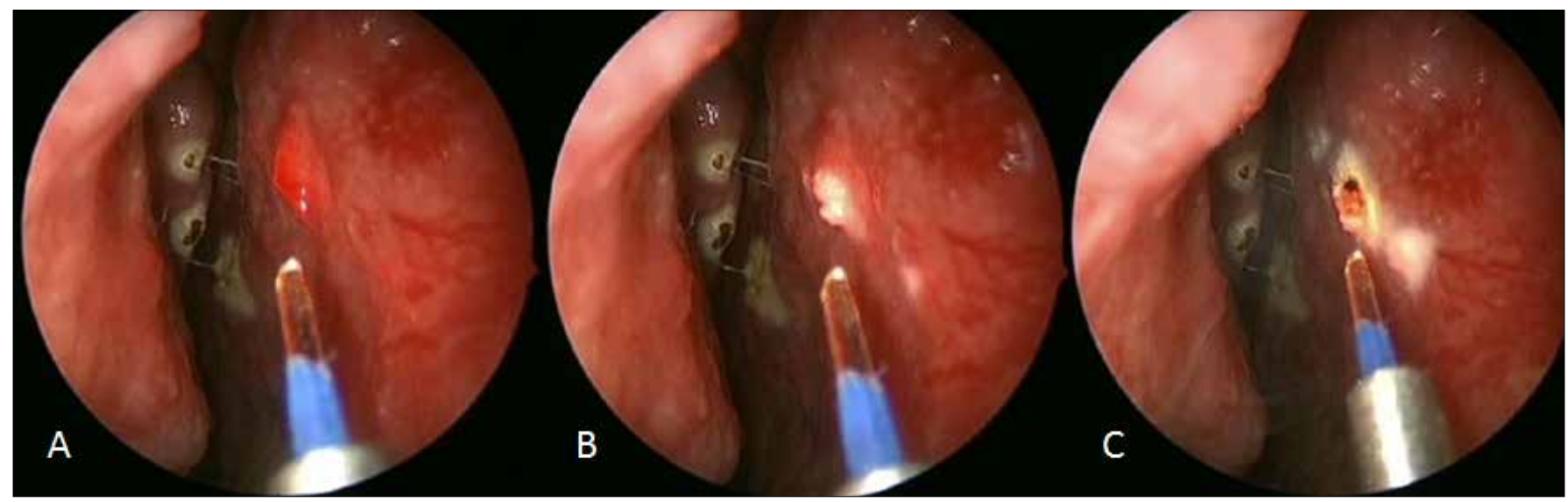

Figure 4. Intraoperative endoscopic sequence showing a thulium laser procedure on a right-side telangiectasia located on the nasal septum.

our treatment: 18 patients (40.9\%) after one procedure, 8 patients $(18.2 \%)$ after two procedures, 12 patients (27.3\%) after three procedures, and 6 patients $(13.6 \%)$ after four or more procedures. In most of these patients, previous surgery in another hospital was performed, which could explain the relatively high rate of septal perforations in our group.

\section{Discussion}

Epistaxis in HHT remains a problem with regards to definitive treatment: current therapies permit control of nosebleeds, but not complete resolution. As stated by Silva et al., firstline treatment of HHT-related nosebleeds includes hygiene of the nasal cavities and avoidance of triggering factors ${ }^{7}$. Different therapies, both medical and surgical, have been proposed in the literature ${ }^{5,8-45}$. In our opinion, endoscopic endonasal mini-invasive techniques have several advantages over other techniques, and these are represented by less mor- bidity, reduced trauma of nasal mucosa, low risk of septal perforation, treatment repeatability, no need for post-surgical nasal packing, the possibility of local anaesthesia and short time of hospitalisation. A review of the literature suggests that the choice of treatment should be based on the severity of nosebleeds: in cases of bleeding of mild entity, a miniinvasive technique can be proposed; on the other hand, in patients with severe epistaxis more invasive surgeries should be chosen (e.g. septodermoplasty, septectomy, closure of the nostrils) ${ }^{10}$. However, in 2013, our group demonstrated the efficacy and long-term benefit of a mini-invasive approach (APC) in a group of HHT patients affected by severe epistaxis with a history of blood transfusion ${ }^{16}$.

In this paper, we report our 20-year experience in the surgical management of epistaxis in HHT, focusing on endoscopic mini-invasive techniques. The Department of Otorhinolaryngology at I.R.C.C.S. Policlinico San Matteo in Pavia is a reference centre for diagnosis and treatment of

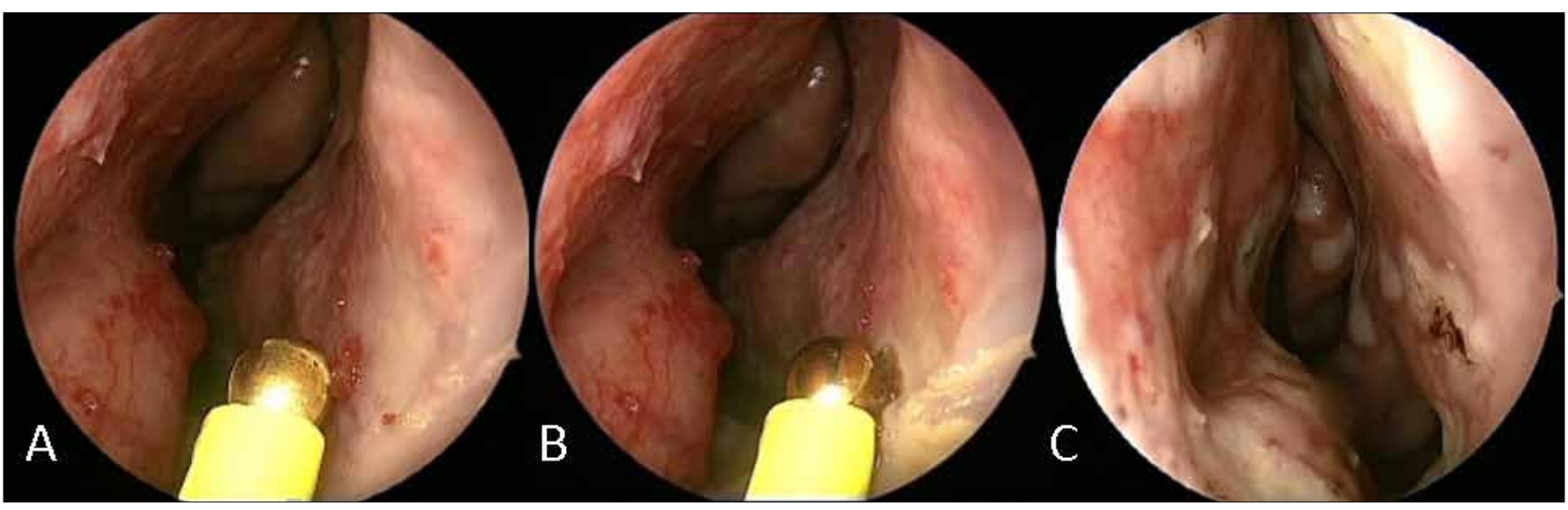

Figure 5. Intraoperative endoscopic sequence showing the quantum molecular resonance technology procedure on a left-side telangiectasia located on the inferior turbinate/nasal valve. 
HHT in Italy, and, over the period analysed (1996-2015), 591 patients with a diagnosis of HHT (according to Curacao criteria) were referred to our centre. The first concept that should be stressed is that only $54.7 \%$ of these patients required surgery for control of epistaxis. This is, to the best of our knowledge, one of the most extensive reported case series on epistaxis surgical treatment in HHT. For the remaining 268 patients, although epistaxis was still present (in fact, it is usually the most common symptom that leads to diagnostic suspicion), quality of life-related to this problem was deemed acceptable and did not require further interventions. Another interesting piece of data is that in 175 patients $(54.2 \%)$, a single surgical procedure was effective to obtain acceptable control of epistaxis (median followup: 48 months), while 148 patients $(45.8 \%)$ required more than one procedure over time; even if not objective, this is a good outcome measure of patient satisfaction with epistaxis control. In our opinion, in fact, it is essential to take into consideration the personal satisfaction of each patient, given that each treatment used for epistaxis in HHT is symptomatic. According to this management strategy, Sautter and Smith also stated in 2016 that, regardless of treatment modality, HHT-related epistaxis would continue ${ }^{10}$.

The mean number of surgical procedures in our group was 2.1 (1.9 in females and 2.3 in males, no significant difference). No significant difference was reported between $A C V R L 1$ and $E N G$ patients regarding the number of procedures. Repetition of a mini-invasive surgical procedure, given its low risk of short-term and long-term complications (44/323 patients developed a septal perforation during treatment, most underwent previous repeated cauterisations in other hospitals) is possible when nasal bleeding returns and has a negative impact on the quality of life. A "staged" procedure should be performed when telangiectasias are present on opposing sides of the anterior nasal septum in order to avoid septal perforation. Moreover, some authors report that submucosal injections of bevacizumab associated with surgical treatment may increase the risk of perforation ${ }^{10}$.

Regarding the characteristics of nasal telangiectasias, data was available for 160 of 323 patients (49.5\%): the most common pattern was mixed (90 patients, $56.3 \%$ ), followed by the large ( 56 patients, $35 \%$ ), and punctate patterns (14 patients, $8.7 \%$ ). The nasal septum and lateral nasal walls were involved, respectively, in $91.9 \%$ and $91.3 \%$ of patients, nasal floor in $43.7 \%$ and nasal valve in $31 \%$. Wide variability can be found not only in the nasal pattern of telangiectasias, but also in the number of nasal subsites involved, even in patients with the same pattern. Furthermore, we confirmed that different subsites in nasal fossae, and even the same subsite, can present similar or different patterns. We also observed a higher incidence of mixed and large patterns in surgical candidates; this is in accordance with a previous paper in which we observed a significantly higher frequency of nosebleeds in patients presenting the large pattern ${ }^{6}$.

Regarding surgical technique applied, APC was the instrument of choice in most of our patients (661 procedures, 97.3\%), while lasers and quantum molecular resonance technology were used only in $2.7 \%$ of cases. Indeed, APC is our instrument of choice in the treatment of epistaxis in HHT patients independently of preoperative epistaxis severity, which was moderate or severe before surgery in all patients ${ }^{14,16}$. Bergler first described APC treatment of nosebleeds in 1999 on 12 HHT patients ${ }^{17}$. From a technical point of view, APC is based on high-frequency electric energy transmitted through ionised argon gas. The generator is set at 40-60 W and the argon gas flow at $1.2 \mathrm{~L} / \mathrm{min}$. Endoscopic endonasal visualisation permits selective treatment in a noncontact mode of telangiectasias located along all the nasal fossae (also in their posterior portion) and in the nasopharynx. Coagulation of tissue is limited to a 1-2 $\mathrm{mm}$ depth. This permits low risk of local tissue damage because the temperature is rarely over $100^{\circ} \mathrm{C}$. Finally, the applicator tips can be sterilised, and the cost of argon gas is very low.

In the literature, multiple techniques have been described for endoscopic surgical treatment of nasal telangiectasias (Tab. III). Ablative therapies, such as sclerotherapy, electrosurgery and laser treatment, show good outcomes in reducing epistaxis in HHT patients. Sclerotherapy with foamed sodium tetradecyl sulfate has been shown to be effective and safe in four studies, including one randomised clinical trial ${ }^{20-23}$. The potential side effects are tissue necrosis, cellulitis at the site of injection and, more rarely, anaphylaxis, pulmonary embolus and permanent blindness due to central retinal artery or ophthalmic artery occlusion ${ }^{24}$.

Bipolar electrosurgery is preferable to monopolar electrosurgery due to the lower risk of septal perforation, and Ghaheri et al. reported on the efficacy of bipolar cautery for epistaxis treatment in HHT ${ }^{25}$.

Laser photocoagulation is also a viable option, and many different types of laser exist ${ }^{18,26,29}$. Lasers with higher tissue penetration that use haemoglobin as a chromophore, such as the Nd:YAG laser, are preferred over lasers with less penetration. The problem with laser use is that not all devices can be used with flexible fibres, and the manoeuverability inside nasal cavities can be limited. Moreover, increased thermal damage to surrounding tissue is a concern when using lasers.

Multiple uncontrolled series demonstrated that laser treatments are efficient in reducing epistaxis duration, frequency and severity in HHT patients ${ }^{14,16-18,27-31}$. 
Table III. Surgical techniques for epistaxis treatment in HHT patients.

\begin{tabular}{|c|c|c|c|c|c|}
\hline Study & Study design & $\begin{array}{l}\text { No. of } \\
\text { patients }\end{array}$ & Treatment & Outcome of interest & Results \\
\hline Boyer H. et al., $2011^{20}$ & Retrospective & 7 & Sclerotherapy & $\begin{array}{l}\text { Epistaxis frequency and } \\
\text { severity }\end{array}$ & $100 \%$ improved \\
\hline Morais D. et al., $2012^{21}$ & Retrospective & 45 & Sclerotherapy & $\begin{array}{l}\text { Epistaxis frequency and } \\
\text { severity }\end{array}$ & 95\% Improved \\
\hline Boyer H. et al., $2015^{22}$ & $\begin{array}{l}\text { Randomised } \\
\text { controlled trial }\end{array}$ & 17 & Sclerotherapy & ESS & Improved \\
\hline $\begin{array}{l}\text { Esteban-Casado S. et al., } \\
2019^{23}\end{array}$ & Cross-sectional & 38 & $\begin{array}{l}\text { Sclerotherapy } \\
\text { and topical nasal } \\
\text { propranolol }\end{array}$ & ESS, VAS, EQ-5D & Improved \\
\hline Ghaheri B. et al., $2006^{25}$ & Retrospective & 18 & Bipolar cautery & $\begin{array}{l}\text { Need for recurrent } \\
\text { intervention }\end{array}$ & $\begin{array}{l}\text { Recurrent intervention in } 50 \% \\
\text { at a mean follow-up of } 2.3 \\
\text { years }\end{array}$ \\
\hline Bergler W. et al., $1999^{17}$ & Prospective & 12 & APC & $\begin{array}{l}\text { Epistaxis frequency and } \\
\text { intensity }\end{array}$ & Improved \\
\hline Pagella F. et al., $2006^{14}$ & Prospective & 36 & APC & Reported bleeding & $100 \%$ reduction at 6 months \\
\hline Pagella F. et al., $2013^{16}$ & Retrospective & 26 & APC & Epistaxis score & Improved at 12 months \\
\hline Jørgensen G. et al., $2011^{28}$ & Prospective & 30 & Laser & Epistaxis duration & Reduced at 1.5 and 6 months \\
\hline Kuan E.C. et al., $2017^{31}$ & Retrospective & 20 & Laser & SNOT-22 & Improved at 1.5 months \\
\hline Fiorella M.L. et al., $2012^{18}$ & Retrospective & 24 & Diode laser & $\begin{array}{l}\text { Epistaxis frequency and } \\
\text { severity }\end{array}$ & Improved \\
\hline Poje G. et al., $2017^{32}$ & Retrospective & 17 & Diode laser & $\begin{array}{l}\text { Epistaxis frequency and } \\
\text { severity }\end{array}$ & Improved \\
\hline Papaspyrou G. et al., $2016^{29}$ & Retrospective & 38 & Nd:YAG laser & $\begin{array}{l}\text { Need for recurrent } \\
\text { intervention }\end{array}$ & $\begin{array}{l}18 \% \text { recurrent intervention at a } \\
\text { mean follow-up of } 3 \text { years }\end{array}$ \\
\hline Papaspyrou G. et al., $2017^{30}$ & Prospective & 45 & Nd:YAG laser +/- APC & $\begin{array}{l}\text { Need for recurrent } \\
\text { intervention }\end{array}$ & $\begin{array}{c}20-33 \% \text { recurrent intervention } \\
\text { at 3-10 years }\end{array}$ \\
\hline Joshi H. et al., $2011^{36}$ & Case series & 5 & Coblation & Epistaxis control & $80 \%$ of patients \\
\hline Mortuaire G. et al., $2013^{34}$ & Prospective & 16 & Coblation & $\begin{array}{l}\text { Epistaxis frequency and } \\
\text { duration }\end{array}$ & Reduced frequency at 6 months \\
\hline Rotenberg B. et al., $2015^{35}$ & Retrospective & 37 & Coblation & ESS & Improved at 6 months \\
\hline Luk L. et al., $2014^{27}$ & Prospective & 11 & $\begin{array}{c}\text { Coblation vs KTP } \\
\text { laser }\end{array}$ & ESS & No difference in mean ESS \\
\hline Ishibashi T. et al., $2003^{33}$ & Case report & 2 & $\begin{array}{c}\text { Harmonic } \\
\text { Scalpel } \\
\text { Harmonic scalpel }\end{array}$ & Frequency of epistaxis & Improved \\
\hline Ichimura K. et al., $2006^{38}$ & Retrospective & 15 & Septodermoplasty & Patient satisfaction & $100 \%$ satisfied \\
\hline Lesnik G.T. et al., $2007^{15}$ & Retrospective & 9 & $\begin{array}{l}\text { Septodermoplasty } \\
\text { with septectomy }\end{array}$ & $\begin{array}{l}\text { Epistaxis frequency, QoL, } \\
\text { blood transfusions }\end{array}$ & $\begin{array}{l}100 \% \text { improved QoL, blood } \\
\text { transfusion reduced }\end{array}$ \\
\hline Levine C.G. et al., $2008^{39}$ & Retrospective & 106 & Septodermoplasty & QoL & $\begin{array}{l}62 \% \text { responded and } 86 \% \\
\text { improved }\end{array}$ \\
\hline Harvey R. et al., $2008^{37}$ & Retrospective & 33 & Septodermoplasty & Frequency of KTP laser & $\begin{array}{c}\text { Frequency of KTP laser } \\
\text { treatment decreased }(p= \\
0.012)\end{array}$ \\
\hline Rimmer J. et al., $2014^{40}$ & Prospective & 7 & Septodermoplasty & $\begin{array}{l}\text { Epistaxis frequency and } \\
\text { severity }\end{array}$ & $100 \%$ improvement \\
\hline Lee J.M. et al., $2019^{44}$ & Prospective & 7 & $\begin{array}{l}\text { Temporary nasal } \\
\text { occlusion with } \\
\text { Floseal }^{\circledR}\end{array}$ & $\begin{array}{c}\text { ESS and clinical assessment } \\
\text { of nasal cavity }\end{array}$ & $\begin{array}{c}\text { No significant ESS } \\
\text { improvement( }(p=0.179) ; \\
\text { clinical assessment of nasal } \\
\text { cavity improved }(p=0.0088) \\
\text { at } 1 \text { month }\end{array}$ \\
\hline Hosni A.A. et al., $1994^{13}$ & Case series & 2 & Nasal closure & Epistaxis frequency & Improved \\
\hline
\end{tabular}


Table III. (follows).

\begin{tabular}{|c|c|c|c|c|c|}
\hline Study & Study design & $\begin{array}{l}\text { No. of } \\
\text { patients }\end{array}$ & Treatment & Outcome of interest & Results \\
\hline Ichimura K. et al., $2012^{41}$ & Prospective & 7 & Nasal closure & Epistaxis cessation & $57 \%$ success \\
\hline Richer S. et al., $2012^{42}$ & Retrospective & 43 & Nasal closure & Epistaxis cessation & $\begin{array}{l}84 \% \text { responded and } 83 \% \\
\text { success }\end{array}$ \\
\hline Lund V. et al., $2017^{12}$ & Retrospective & 100 & Nasal closure & Epistaxis cessation & $\begin{array}{c}50 \% \text { responded and } 94 \% \\
\text { success }\end{array}$ \\
\hline Andersen J.H. et al., $2020^{43}$ & Retrospective & 10 & Nasal closure & GBI & $\begin{array}{c}\text { Overall GBI score of } 38.05 \\
\text { with an average follow-up } 66 \\
\text { months }\end{array}$ \\
\hline
\end{tabular}

ESS: Epistaxis Severiry Score; VAS: visual analoge scale; EQ-5D: EuroQol-5D scale; APC: Argon plasma coagulation; SNOT-22: Sinonasal outcome test-22; QoL: Quality of life; KTP: Potassium-titanyl-phosphate; GBI: Glasgow benefit inventory.

Ishibashi and Takamatsu described the intraoperative application of the harmonic scalpel (an ultrasonic system) in two HHT patients; highlighting the lack of damage to the surrounding mucosa, but long-term results were not reported ${ }^{33}$. Some authors described coblation in the treatment of HHTrelated nosebleeds; this method has been shown to be a useful alternative to other surgical devices, improving nosebleed severity ${ }^{33-35}$.

Septodermoplasty and nasal closure are considered useful in patients whose epistaxis fails to respond sufficiently to ablative therapies ${ }^{35}$. According to several authors, septodermoplasty improves both quality of life and epistaxis severity ${ }^{37-40}$. This surgical technique permits an adequate treatment of septal lesions, while it does not allow for epistaxis control in situations where bleeding originates in the lateral wall, which was involved in more than $90 \%$ of patients in our group. Worsening sinus infections, decreased sense of smell and crusting are the major complications ${ }^{36}$.

Only a few studies have investigated nasal closure outcomes, but there is general agreement on the efficacy in controlling nose bleeds, with an epistaxis cessation rate ranging from 57 to $94 \%{ }^{41-43}$.

The major limit in comparing different surgical techniques in HHT is that there is no homogeneity among outcomes defining surgical success: some authors used epistaxis severity score as the primary outcome, while others report only patient satisfaction or quality of life (Tab. III).

A fundamental preoperative step is careful preparation of the nasal cavities before surgery with local decongestion and meticulous cleaning of crusting and blood clots. In case of profuse and uncontrollable intraoperative bleeding, we suggest a "three-hands" or even a "four-hands" procedure: two surgeons in the operative room, one holding the endoscope and the APC and the other holding the suction tube (one or two if necessary). Moreover, an intranasal haemostatic matrix can be applied during surgery to permit adequate management of severe intraoperative bleeding and better visualisation of the intraoperative field: we successfully used these devices in 83 procedures (12.2\%). To the best of our knowledge, only one description of the intranasal use of a haemostatic matrix in HHT has been reported ${ }^{44}$.

Possible drawbacks of this study include the lack of objective outcome measures, its retrospective nature and the lack of a control group treated with different procedures (e.g. APC $v s$ other techniques).

\section{Conclusions}

Recurrent epistaxis from telangiectasias of the nasal mucosa is a common manifestation present in more than $95 \%$ of HHT patients. Current therapies cannot permit a definitive resolution of the symptom, but only temporary control of nosebleeds and improvement in the quality of life. Herein, we describe our 20-year experience in the endoscopic surgical treatment of epistaxis in a large group of 323 HHT patients. Endoscopic endonasal mini-invasive surgical options, and in particular APC, allowed good control of epistaxis without major complication and nasal packaging. These treatment modalities are repeatable, non-invasive and can be used as a first step even in patients with severe epistaxis. In conclusion, since no treatment could be considered definitive and the natural history of HHT-related nosebleeds is unknown, in our opinion the application of mini-invasive treatment modalities that permit preservation of nasal anatomy and physiology should be the approach of choice.

\section{References}

1 Faughnan ME, Palda VA, Garcia-Tsao G, et al. International guidelines for the diagnosis and management of hereditary haemorrhagic telangiectasia. J Med Genet 2011;48:73-87. https://doi.org/10.1136/ jmg.2009.069013

2 Olivieri C, Pagella F, Semino L, et al. Analysis of ENG and ACVRL1 genes in 137 HHT Italian families identifies 76 different mutations (24 novel). Comparison with other European studies. J Hum Genet 2007;52:820-9. https://doi.org/10.1007/s10038-007-0187-5 
3 Pagella F, Pusateri A, Chu F, et al. Narrow-band imaging in the endoscopic evaluation of hereditary hemorrhagic telangiectasia patients. Laryngoscope 2013;123:2967-8. https://doi.org/10.1002/lary.24338

4 Pagella F, Pusateri A, Zaccari D, et al. Fluorescein-guided intraoperative endoscopy in patients with hereditary hemorrhagic telangiectasia: first impressions. Int Forum Allergy Rhinol 2017;7:300-3. https://doi. org/10.1002/alr.21880

5 Invernizzi R, Quaglia F, Klersy C, et al. Efficacy and safety of thalidomide for the treatment of severe recurrent epistaxis in hereditary haemorrhagic telangiectasia: results of a non-randomised, singlecentre, phase 2 study. Lancet Haematol 2015;2:e465-e73. https://doi. org/10.1016/S2352-3026(15)00195-7

6 Pagella F, Colombo A, Matti E, et al. Correlation of severity of epistaxis with nasal telangiectasias in hereditary hemorrhagic telangiectasia (HHT) patients. Am J Rhinol Allergy 2009;23:52-8. https:// doi.org/10.2500/ajra.2009.23.3263

7 Silva BM, Hosman AE, Devlin HL, et al. Lifestyle and dietary influences on nosebleed severity in hereditary hemorrhagic telangiectasia. Laryngoscope 2013;123:1092-9. https://doi.org/10.1002/ lary. 23893

8 Gaillard S, Dupuis-Girod S, Boutitie F, et al. Tranexamic acid for epistaxis in hereditary hemorrhagic telangiectasia patients: a European cross-over controlled trial in a rare disease. J Thromb Haemost 2014;12:1494-502. https://doi.org/10.1111/jth.12654

9 Dupuis-Girod S, Ambrun A, Decullier E, et al. ELLIPSE Study: a Phase 1 study evaluating the tolerance of bevacizumab nasal spray in the treatment of epistaxis in hereditary hemorrhagic telangiectasia. mAbs 2014;6:793-8. https://doi.org/10.4161/mabs.28025

10 Sautter NB, Smith TL. Treatment of hereditary hemorrhagic telangiectasia-related epistaxis. Otolaryngol Clin North Am 2016;49:63954. https://doi.org/10.1016/j.otc.2016.02.010

11 Faughnan ME, Mager JJ, Hetts SW, et al. Second International Guidelines for the diagnosis and management of hereditary hemorrhagic telangiectasia. Ann Intern Med 2020;173:989-1001. https://doi. org/10.7326/M20-1443

12 Lund VJ, Darby Y, Rimmer J, et al. Nasal closure for severe hereditary haemorrhagic telangiectasia in 100 patients. The Lund modification of the Young's procedure: a 22-year experience. Rhinology 2017;55:135-41. https://doi.org/10.4193/Rhin16.315

13 Hosni AA, Innes AJ. Hereditary haemorrhagic telangiectasia: Young's procedure in the management of epistaxis. J Laryngol Otol 1994;108:754-7. https://doi.org/10.1017/s0022215100128026

14 Pagella F, Semino L, Olivieri C, et al. Treatment of epistaxis in hereditary hemorrhagic telangiectasia patients by argon plasma coagulation with local anesthesia. Am J Rhinol 2006;20:421-5. https://doi. org/10.2500/ajr.2006.20.2886

15 Lesnik GT, Ross DA, Henderson KJ, et al. Septectomy and septal dermoplasty for the treatment of severe transfusion-dependent epistaxis in patients with hereditary hemorrhagic telangiectasia and septal perforation. Am J Rhinol 2007;21:312-5. https://doi.org/10.2500/ ajr.2007.21.3017

16 Pagella F, Matti E, Chu F, et al. Argon plasma coagulation is an effective treatment for hereditary hemorrhagic telangiectasia patients with severe nosebleeds. Acta Otolaryngol 2013;133:174-80. https://doi.or $\mathrm{g} / 10.3109 / 00016489.2012 .718097$

17 Bergler W, Riedel F, Baker-Schreyer A, et al. Argon plasma coagulation for the treatment of hereditary hemorrhagic telangiectasia. Laryngoscope 1999;109:15-20. https://doi.org/10.1097/00005537199901000-00004

18 Fiorella ML, Lillo L, Fiorella R. Diode laser in the treatment of epistaxis in patients with hereditary haemorrhagic telangiectasia. Acta Otorhinolaryngol Ital 2012;32:164-9.
19 Chin CJ, Rotenberg BW, Witterick IJ. Epistaxis in hereditary hemorrhagic telangiectasia: an evidence based review of surgical management. J Otolaryngol Head Neck Surg 2016;45:3. https://doi. org/10.1186/s40463-016-0116-8.

20 Boyer H, Fernandes P, Duran O, et al. Office-based sclerotherapy for recurrent epistaxis due to hereditary hemorrhagic telangiectasia: a pilot study. Int Forum Allergy Rhinol 2011;1:319-23. https://doi. org/10.1002/alr.20053

21 Morais D, Millás T, Zarrabeitia R, et al. Local sclerotherapy with polydocanol (Aethoxysklerol ${ }^{\circledR}$ ) for the treatment of epistaxis in renduosler-weber or hereditary hemorrhagic telangiectasia (HHT): 15 years of experience. Rhinology 2012;50:80-6. https://doi.org/10.4193/Rhino11.211

22 Boyer H, Fernandes P, Le C, et al. Prospective randomized trial of sclerotherapy vs standard treatment for epistaxis due to hereditary hemorrhagic telangiectasia. Int Forum Allergy Rhinol 2015;5:435-40. https://doi.org/10.1002/alr.21484

23 Esteban-Casado S, Martín de Rosales Cabrera AM, Usarralde Pérez A, et al. Sclerotherapy and topical nasal propranolol: an effective and safe therapy for HHT-epistaxis. Laryngoscope 2019;129:221623. https://doi.org/10.1002/lary.27930

24 Hanks JE, Hunter D, Goding GS Jr, et al. Complications from of fice sclerotherapy for epistaxis due to hereditary hemorrhagic telangiectasia (HHT or Osler-Weber-Rendu). Int Forum Allergy Rhinol 2014;4:422-7. https://doi.org/10.1002/alr.2128

25 Ghaheri BA, Fong KJ, Hwang PH. The utility of bipolar electrocautery in hereditary hemorrhagic telangiectasia. Otolaryngol Head Neck Surg 2006;134:1006-9. https://doi.org/10.1016/j.otohns.2005.12.019

26 Abiri A, Goshtasbi K, Maducdoc M, et al. Laser-assisted control of epistaxis in hereditary hemorrhagic telangiectasia: a systematic review. Lasers Surg Med 2020;52:293-300. https://doi.org/10.1002/ $1 \mathrm{sm} .23147$

27 Luk L, Mace JC, Bhandarkar ND, et al. Comparison of electrosurgical plasma coagulation and potassium-titanyl-phosphate laser photocoagulation for treatment of hereditary hemorrhagic telangiectasiarelated epistaxis. Int Forum Allergy Rhinol 2014;4:640-5. https://doi. org/10.1002/alr.21328

28 Jørgensen G, Lange B, Wanscher JH, et al. Efficiency of laser treatment in patients with hereditary hemorrhagic telangiectasia. Eur Arch Otorhinolaryngol 2011;268:1765-70. https://doi.org/10.1007/s00405011-1677-9

29 Papaspyrou G, Schick B, Al Kadah B. Nd:YAG laser treatment for extranasal telangiectasias: a retrospective analysis of 38 patients with hereditary hemorrhagic telangiectasia and review of the literature. ORL J Otorhinolaryngol Relat Spec 2016;78:245-51. https://doi. org/10.1159/000447949

30 Papaspyrou G, Hecker D, Linxweiler M, et al. Combined therapy for epistaxis by hereditary hemorrhagic teleangiectasia: a 3-year follow up study on 45 patients. J Craniomaxillofac Surg 2017;45:1179-82. https://doi.org/10.1016/j.jcms.2017.05.018

31 Kuan EC, Peng KA, Thompson CF, et al. Sinonasal quality of life outcomes following laser treatment of epistaxis related to hereditary hemorrhagic telangiectasia. Lasers Med Sci 2017;32:527-31. https:// doi.org/10.1007/s10103-017-2144-7

32 Poje G, Kavanagh MM. Hereditary hemorrhagic telangiectasia-laser treatment of epistaxis. Ear Nose Throat J 2017;96:E10-E4.

33 Ishibashi T, Takamatsu S. Hereditary hemorrhagic telangiectasis treated by the harmonic scalpel. Head Neck 2003;25:333-6. https:// doi.org/10.1002/hed.10201

34 Mortuaire G, Boute O, Hatron PY, et al. Pilot study of submucosal radiofrequency for epistaxis in hereditary hemorrhagic telangiectasia. Rhinology 2013;51:355-60. https://doi.org/10.4193/Rhin13.027 
35 Rotenberg B, Noyek S, Chin CJ. Radiofrequency ablation for treatment of hereditary hemorrhagic telangiectasia lesions: "How I do it". Am J Rhinol Allergy 2015;29:226-7. https://doi.org/10.2500/ ajra.2015.29.4163

36 Joshi H, Woodworth BA, Carney AS. Coblation for epistaxis management in patients with hereditary haemorrhagic telangiectasia: a multicentre case series. J Laryngol Otol 2011;125:1176-80. https://doi. org/10.1017/S0022215111001733

37 Harvey RJ, Kanagalingam J, Lund VJ. The impact of septodermoplasty and potassium-titanyl-phosphate (KTP) laser therapy in the treatment of hereditary hemorrhagic telangiectasia-related epistaxis. Am J Rhinol 2008;22:182-7. https://doi.org/10.2500/ ajr.2008.22.3145

38 Ichimura K, Tanaka H, Yamamoto Y, et al. Nasal dermoplasty for Japanese hereditary hemorrhagic telangiectasia. Auris Nasus Larynx 2006;33:423-8. https://doi.org/10.1016/j.anl.2006.03.001

39 Levine CG, Ross DA, Henderson KJ, et al. Long-term complications of septal dermoplasty in patients with hereditary hemorrhagic telangiectasia. Otolaryngol Head Neck Surg 2008;138:721-4. https://doi. org/10.1016/j.otohns.2008.01.005

40 Rimmer J, Lund VJ. A modified technique for septodermoplasty in hereditary hemorrhagic telangiectasia. Laryngoscope 2014;124:67-9. https://doi.org/10.1002/lary.24303

${ }^{41}$ Ichimura K, Kikuchi H, Imayoshi S, et al. Are patients with severe epistaxis caused by hereditary hemorrhagic telangiectasia satisfied with nostril closure surgery? Auris Nasus Larynx 2012;39:59-64. https://doi.org/10.1016/j.anl.2011.03.003

42 Richer SL, Geisthoff UW, Livada N, et al. The Young's procedure for severe epistaxis from hereditary hemorrhagic telangiectasia. Am J Rhinol Allergy 2012;26:401-4. https://doi.org/10.2500/ ajra.2012.26.3809

43 Andersen JH, Kjeldsen AD. Patient-recorded benefit from nasal closure in a Danish cohort of patients with hereditary haemorrhagic telangiectasia. Eur Arch Otorhinolaryngol 2020;277:791-800. https:// doi.org/10.1007/s00405-019-05758-1

${ }_{44}$ Lee JM, Wu V, Faughnan ME, et al. Prospective pilot study of Floseal $^{\circledR}$ for the treatment of anterior epistaxis in patients with hereditary hemorrhagic telangiectasia (HHT). J Otolaryngol Head Neck Surg 2019;48:48. https://doi.org/10.1186/s40463-019-0379-y

45 Meccariello G, Georgalas C, Montevecchi F, et al. Management of idiopathic epistaxis in adults: what's new? Acta Otorhinolaryngol Ital 2019;39:211-9. https://doi.org/10.14639/0392-100X-2155 